\title{
Гендерный аспект обряда «Вождение Стрелы» (белорусско-российское пограничье)
}

\section{Ирина Смирнова}

Центр исследований белорусской культуры, языка и литературы Наџиональной академии наук Беларуси smirnova_2007@tut.by

\begin{abstract}
Аннотация: Обряд вождения «Стрелы», главными участниками которого были совершеннолетние девушки, рассматривается как ритуальное единение женского коллектива, пик девичьей зрелости и активности. В текстах «стрельных» песен ярко выражена оппозиция женский/мужской, где двойственность проявляется как интерес, влечение к мужскому началу и агрессивность по отношению к нему. Обряд «Вождение стрелы» является последним этапом перехода к девичьему совершеннолетию. Тема рассмотрена на основе традиции д. Неглюбка Ветковского района Гомельской области Беларуси.

Ключевые слова: обряды перехода, весенняя обрядность, гендерная оппозиция в обряде
\end{abstract}

Весенне-летний обряд «Вождение и похорон Стрелы/сулы» («Ваджэнне і пахаванне Стралы») - архаичный весенний обряд Восточного Полесья, который тесно связан с охранительной и аграрной продуцирующей магией. Приурочен к Пасхальной неделе или празднику Вознесения Господня. Регион распространения - Посожье (территория между реками Днепром и Припятью), частично Гомельская область Беларуси, Черниговская область Украины и Брянская область России. 
Основные ритуальные действия: сбор участников, вождение хороводов и шествия рядами по улицам, выход в поле, «похороны стрелы» (закапывание в землю мелких предметов: колец, серег, лент, монет, колосьев), качание по житу, возвращение в деревню. Участниками обряда были женщины, девушки и девочки, а также ряженые - «дед» и «баба». Название обряда произошло от зачина хороводной песни «Да й ішла стряла у канец сяла", “Як пушчу стралу да па ўсём сялу”. «Стрела» ритуальной песни символизировала молнию, а слёзы, проливаемые по сюжету песни женщинами, - дождь, поэтому и сам обряд связывался с вызыванием дождя. «Стрелой» также называлось само шествие, песня, группа исполнительниц и предметы, которые закапывались в конце обряда на поле. В ходе обряда женщины, кроме обычных хороводов, водят сложные по конфигурации «кривые танки» с участием детей.

Обряд «Вождения и похорон Стрелы» в Сожском Поднепровье достаточно хорошо изучен исследователями традиционной культуры, однако гендерному аспекту данного обряда было уделено чрезвычайно мало внимания. В годовой системе календарных праздников обряд вождения Стрелы - праздник пограничья весны-лета, с ярко выраженной аграрной семантикой, в которой взаимосвязаны продуцирующая и охранительная магия (Гусев 1986: 73). Главными участниками обряда были совершеннолетние девушки (Романов 1912: 178; Каршукоў 1926: 41-42; Гусев 1986: 69) и бездетные молодые женщины.

Изучение процессов взросления и этапов перехода девушек в иную возрастную группу молодежи, связанных с ними изменений в традиционном костюме позволяют говорить, что обряд пограничья весны-лета в этом процессе имел основное значение. Переход девушек в группу совершеннолетних происходил в несколько этапов за достаточно короткий промежуток времени - от осени до весны. Практически все названные этапы перемены социального положения девушек отмечены переменами в традиционном девичьем костюме, что хорошо прослеживается на примере неглюбского строя (гомельско-брянское пограничье).

Первым шагом на пути к совершеннолетию можно считать переход девушки в группу самых старших, которых называли «невесты». Это давало возможность с начала осени присутствовать на рабочих вечерах-«супрадках», участвовать в играх и развлечениях. 


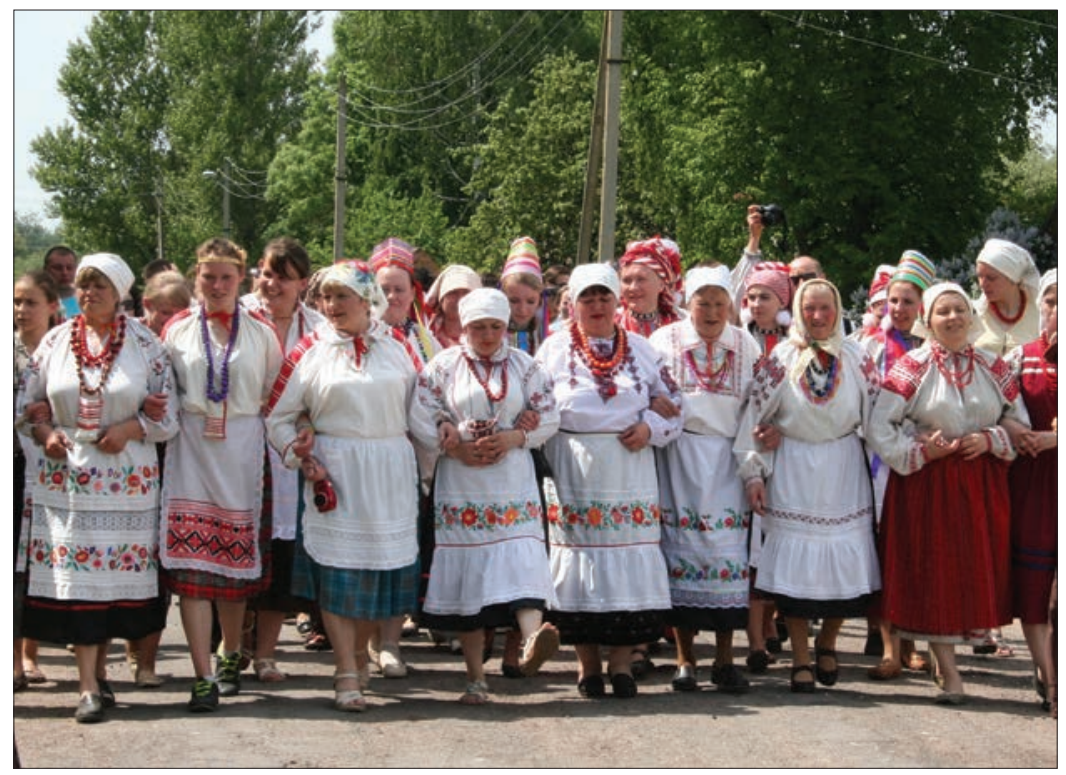

Фото 1. Обряд вождения Стрелы. Шествие по улице. д. Столбун, Ветковский р-н, Гомельская обл. Республика Беларусь. Фото И. Ю. Смирновой, 2015.

Следующим этапом «взросления» для девушки был приход на праздничные колядные «игрища» в традиционном головном уборе («кубке»). Это хорошо наблюдается в особенностях костюма: девичий комплекс (рубаха-«колышки»-пояс) дополняется праздничным головным убором из полного праздничного костюма девушки-«невесты» (костюм с понёвой и «кубком»). Традиционный девичий головной убор неглюбского строя из многоцветных лент выполнял несколько важных фрункций. В первую очередь он выступал в роли возрастного маркера: девушка в «кубке» заявляла о себе как о потенциальной невесте из обеспеченной семьи с прочными родственными связями. Во время праздничных сборов молодежи головной убор служил регулятором взаимоотношений в своей возрастной группе (Смирнова 2004a: 195-196).

Последний этап на пути к совершеннолетию заключался в активном участии девушки в весенних обрядах, а также вы- 
ходе в церковь и на гуляния в один из весенних праздников (Благовещение, Пасха, Вознесение, Троица) в костюме «невесты» (сорочке, насыщенной красным цветом орнаментов, понёве и «кубке») (Смирнова 2008: 94-96). Если девушка не была готова выступить в роли невесты до Троицы, одевание поневы также откладывалось до следующей весны. В частности, Н. И. Лебедева отмечала такие же условия первого выхода в поневе и запрета на ее ношение после Троицы: «... совершеннолетние девушки надевают поневу в первый раз «на Великдень» (Пасха) или на Троицу, как идти к обедне. Если к этим праздникам девушке еще нельзя надеть поневу, то откладывают до следующего года» (Лебедева 1996: 46). Череда праздников весеннего периода давала возможность постепенно присоединиться к группе «невест» - максимальному количеству девушек, достигших не только физической, но и социальной зрелости. Торжественный выход в полном девичьем костюме являлся своеобразной декларацией о своем совершеннолетии и готовности вступить в брак, а также выступал символом единства духовной жизни личности и социума.

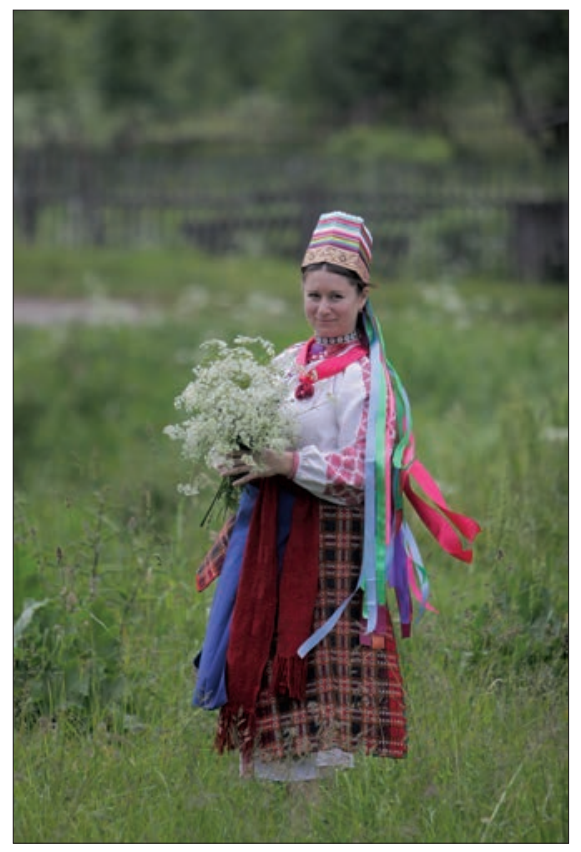

Обряды девичьего совершеннолетия в жизни сельской общины имели даже большую значимость, чем свадьба (Лебедева 1996: 47; Супинский 1932: 118-120). Как отмечали исследователи, «в оценке возраста совершеннолетия преобладали фризиологические и аскриптивные признаки» (т. е. половая зрелость при-

Фото 2. Девушка в праздничном костюме. д. Неглюбка, Ветковский р-н, Гомельская обл. Республика Беларусь. Фото О. Белоусова, 2012. 
писывалась определенной возрастной норме) (Бернштам 1988: 41-42). А. ван Геннеп указывал также на то, что социальное изменение статуса не обязательно привязано к биологическим процессам, таким как наступление половой зрелости, и окончательно утверждается именно в ритуале (Геннеп 1999: 64-70).

Участие в обряде «вождения и похорон Стрелы» можно считать в своем роде «обрядом перехода», с элементами инициации для девушек (в качестве примера см. текст «Па вулицы ж па шырокай...», об испытаниях «девки-семилетки», д. Столбун Ветковского р-на) (БФ 1989: 80-81). Именно в этот период каждая из них должна была продемонстрировать физическую готовность к браку, собственную силу и ловкость (участие в хороводах и играх), владение женскими трудовыми навыками, мастерство и вкус в изготовлении и ношении костюма.

Вторая группа участниц обряда «вождения Стрелы» - молодые бездетные женщины (“маладзіцы”, “малодкі”). По социальному статусу "молодки» занимали промежуточное положение между девушками и женщинами с детьми, и недолгий промежуток времени до первой беременности и родов можно обозначить как лиминальный период. Такая группа не была многочисленной - в XIX - н. XX вв. ежегодно в Коляды и до начала Великого поста венчалось не более 40 молодых пар (Смирнова 2004: 95-96). Эта группа женщин визуально выделялась среди участников любого праздника, поскольку костюм молодых бездетных женщин не имел полноты и завершенности женского костюма: в нем отсутствовала нагрудная одежда («запина»), использовался иной способ завязывания платка (Смирнова 2008: 95-96).

Участие в обряде двух основных групп - совершеннолетних девушек и молодых бездетных женщин - прослеживается и в песенном репертуаре праздника, где хорошо выделяются две большие группы - песни с брачной тематикой, адресованные девушкам или исполняемые от их имени, и песни, которые исполняются от имени замужних женщин.

Ты, зялёненькі падарэшнічак,

Ой калі ж ты рос?

- У Вялікі пост!

Раскідаўся ты у панядзелачак, У панядзелачак - радзі дзевачак, У аўторачак - радзі малодачак. ${ }^{1}$ 
Традиционно в регионе не было слишком ранних и неравных по возрасту браков, чаще молодые являлись сверстниками, или парень был моложе на 1-2 года (Смирнова 2004: 95-96). В весенних песнях со свадебной тематикой, а также в свадебных песнях отсутствует мотив раннего брака и незрелости невесты. Более реальной была вероятность стать женой юного или «старого» мужчины, который не отпускает гулять с подругами, губит девичью красоту, лишает воли, свободы. Этот сюжет присутствует в «стрельных» песнях:

Ой на Стрэчанне, на Благавешчанне

Зіма зь лецечкам сустрякалася!

Танечка ў мамкі красавалася, Трёмы мыламі умывалася.

Первае мылечка - то бялілечка, Друге мылечка - то чарнілечка, Трэццяе мылечка - то красілечка.

Ой няд'дай, мамка, не за старага, Не за старага, не за малага, Ой, аддай, мамка, ды за роўнага! Старага красу у повясе знашу, У повясе знашу, у вузёльчыку! Малага красу у чабаце знашу, У чабаце знашу, пад усцілкаю! Роўнага красу у вянку знашу, У вянку знашу, на галоваццы!;

Проці бацькавых варот я, молада, гуляла. Я гуляла, гуляла, ключі пацяряла... Хто мае ключы найдзе, за таго замуж пайду!

Як пачуў стары чорт мае словечка, На вулачку пашоў, мае ключыкі нашоў. А прападайце, ключы, як за старага іцці! Старый ляжыць - кахе-кахе, а я за йім скаке-скаке. Старый ляжыць, памірае, а я за йім маладая.

Старый ляжыць як засланка, а я за йім як ластаўка....;

Ой, старяц мой, лікамаряц мой, Ён у цагельні сядзіць, Богу моліцща, А мне ж, маладзе, гуляць хочыцца.... ${ }^{4}$

В текстах «стрельных» песен наиболее ярко проявляется один из основных девичьих образов - образ птицы. И сама группа 
девушек в фольклорных текстах сравнивалась со стаей гусей, лебедей, уток. Как отмечала исследовательница Т. А. Бернштам, «...водоплавающие птицы женского рода символизировали половое созревание девушки...» в русских девичьих хороводных песнях (Бернштам 1982: 84). Образ сказочной птицы, присущий традиционной культуре, отчетливо просматривается в праздничном девичьем костюме неглюбского строя. Только девушка, достигшая брачного возраста, могла носить поневу, части которой назывались “крылья, хвост, ковш”, шейное бисерное украшение - “гарлячку”, подвески из гусиного пуха “пушки”. Пестрые ленты "кубка", яркая лента в косе, множество нагрудных лент, бус, оформление зарукавья рубахи “перистыми” орнаментами дополняли образ птицы в брачный период.

Што на нашай вуліцы, на зялёнай мураўцы, Разліў разліваўся з глыбокага возера.

Што па тым па возеры шәры гусі плавалі, Шәры гусі плавалі, шэры гусі стадом.

Налятаў на гусачак, налятаў шызы арол....

Ухапіў ён гусачку, гуску за галоўку.

Гуску за галоўку, за белую шыйку.

За белую шыйку, за правае крыльца.

Крыкнулі-гакнулі гусачкі па гусі:

- Хто й у нас будзе па берагу плысці?

Хто й у нас будзе ключы завадзіці?...

(весенний хоровод (БФ 1989: 91-92)).

«Заводить ключи» («заводзіць ключы») означало начинать хороводы, и в особенности - сложный хоровод «Лука». По воспоминаниям старших женщин, раньше «Луку» и другие сложные хороводы «заводили» только девушки и молодые женщины. Сложность заключалась в том, что в достаточно быстром движении (иногда бегом) надо было неразрывной цепочкой обвести четырех или трех девочек и вывести «Луку» в обычный «танок» (хоровод).

Што на лужку-лужку, на зялёнай траўцы...

Верямей коней пасе, дзеўка воду нясе...

- Дзеўка-дзявіца, напой майго коня.

- Ня буду каня паіці, будзе мяне маці біці, Будзе мяне маці біці, на парозе палажыўшы,

.... На косы ступіўшы

(Кавалёва 2015: 104). 
Дополняет образ девушка/водоплавающая птица девичья весенняя игра «Вуціца (утица)». Одна из девушек давала команду на игру, становилась впереди, остальные - до тридцати человек брались в цепочку за руки и бежали вместе по улице под песню:

Ішла вуціца па беражку,

Ішла па крутому,

Вяла дзяцей за сабою.

Прыскочыла два лашонкі,

Ухапіла два дзіцёнкі.

Ідзі, вуціца, дамой,

Ідзі, серая, дамой,

$\mathrm{У}$ цябе сямера дзяцей,

Восьмы - сынавей,

Дзевятая - унучка,

Каціся, як сучка!

Ритм пения и движения хоровода ускорялся, на последней строке ведущая делала резкий поворот и закручивала всю цепочку так, что последние девушки обязательно падали. Первые должны быть очень сильными, ловкими, чтобы изменить движение следующих за ними. Так называемые «утушные» игры и хороводы широко известны у русских, у белорусов и украинцев встречаются в пограничных с Россией районах. К сожалению, в Неглюбке не зафиксировано названия девушек-ведущих, но у русских в инициативной девичьей группе девушку, которая возглавляла хороводы, начинала игры, управляла девичьим коллективом, называли «утка/гусыня» (Смирнова).

Выход девушек на улицу и участие в весенних обрядах знаменует начало их групповой организации. В обряде пограничья весны-лета консолидированное женское начало в виде самой “стрелы” представляется действительно грозной силой. По мнению Т. А. Бернштам, обострение в этот момент оппозиции мужской / женский «являлось выражением биологического кризиса, свойственного как природному..., так и человеческому миру...» (Бернштам 1988: 178). Ритуальное единение девичье-женского коллектива, агрессия по отношению к мужчинам, вплоть до отрицания брака и идеи смерти мужа были направлены на преодоление данного кризиса.

Девичество в народных традициях всегда противопоставлялось семейной жизни как свобода и неволя, на этом контрасте построены и тексты большинства “стрельных" песен. Вольная жизнь у отца и матери была полна родительской любви, свободы и радости: 


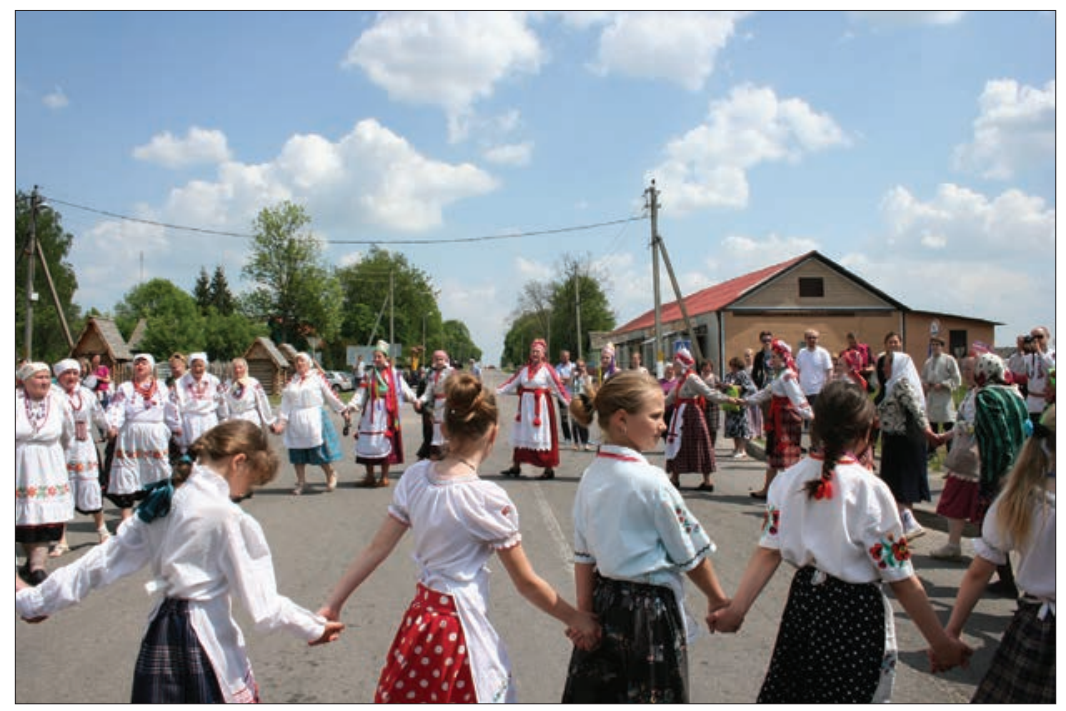

Фото 3. Обряд вождения Стрелы. Хоровод на улице. д. Столбун, Ветковский р-н, Гомельская обл. Республика Беларусь. Фото И. Ю. Смирновой, 2015.

А ў майго таткі харашо жыці, Харашо жыці, вольна хадзіці, Двор пад гарою, сад над вадою... ${ }^{6}$;

Як была я ў бацюшкі й адна доч у нарядзе.

Й адна доч у нарядзе, да як вішанька у садзе.

Ой, як вішанька у садзе, да як рожа ў вагародзе...

(Кавалёва 2015: 91);

Ой ты, саду, мой саду, зеляненькі,

Па ём ходзя парнішачка, ў гуслі грая, За ім ходзя дзяўчоначка, успявая. Яна пела-успявала, дай заснула.

Падыходзя парнішачка разбуджаці:

- Ў стань-прасніся, красна дзеўка, прабудзіся, А ужо цябе родна маці даўно кліча!

Няхай кліча-выклікае, ні чужая.

Яна выйдзе за вароты, ні пасудзя, Яна выйдзя за новыя, да й пахваля. (БФ 1989: 85-86). 
Жизнь замужней женщины в доме свекра и свекрови представлялась совсем в ином свете:

Ой, пад вішанню, пад чарэшанню.

Ой, там Сашанька ручнікі ткала,

Ручнікі ткала, перабівала.

На сярэдзіну белы лебедзі,

Ой, па краёчку- залато кружжа.

Адкуль чорт нанёс майго свёкарку:

Белы лебедзі разляцеліся, Залато кружжа разаткалася.

(БФ 1989: 66);

...Маладыя малодачкі, выхадзіця на улачку, Выхадзіця на улачку, гаварыця па словячку, Гаварыця па словячку, ў каго муж малады.

А ў мяне жы стары чорт, сам на вулачку ня ходзя, Сам на вулачку ня ходзя, мяне, моладу, ня водзя.

Ой, пайду я на часочык, я ж гуляю ўвесь дзянёчык...

(«Проці бацькавых варот я, молада, гуляла...» (Кавалёва 2015: 99-100)).

Песня «На вуліцы дзеўкі гулялі..» ярко демонстрирует стремление «маладзіцы» вернуться к девичьей жизни хоть на короткое время, невзирая на последующее наказание:

На вуліцы дзеўкі гулялі, мяне, маладую гукалі.

$\mathrm{y}$ мяне, маладой, муж ліхой,

Ня пускае пагуляць, дзеўкам песен паспяваць.

Ён пусця позненька, да дзевачак розьненька.

Скрыпкі-бубны я найму, усех дзевак сабяру:

Гуляйце, дзеўкі, да свету, да позняга абеду...

А ты, дзеверка, родны брат, вядзі мяне да дому, ...у сьвекраву камору.... ${ }^{7}$

Песни весеннего цикла можно рассматривать и как отображение будущей семейной жизни, трудностей в отношениях, как предостережение от «лихой» свекрови и свекра, старого или нелюбимого мужа.

В некоторых песнях, приуроченных к обряду вождения Стрелы, прослеживается мотив девичьего и женского своеволия, даже агрессии в отношении парней, нелюбимого/старого мужа. Но такая агрессия скорее коллективная, чем индивидуальная. В песне «Што па троўке-троўкі, зялёнай муроўкі...» молодой парень, одетый вполне празднично и престижно (пуховая ша- 
почка, ситцевая рубашечка, хромовые сапожки), при попытке найти себе пару получает со стороны девушки грозный отпор. По реакции «молодого молодца» можно предположить, что это не первая попытка:

Пайшоў жа хлопчычак, пайшоў дай заплакаў:

- Мамачка радзіма, нашто нарадзіла?

Такога малойчыка дзевачкі ня любяць...

(Кавалёва 2015: 103).

Но коллективная агрессия и нелюбовь преодолевается «жалостью» одной из девушек:

Што па троўке-троўкі, зялёнай муройкі,

Там гуляў моладзец, малады Васілька.

Ён жа сабе дзевачку кліча-выклікае.

А тая дзяўчоначка яго ня узьлюбіла,

Пуховаю шапачку з галоўкі зьбіла,

Сітцаву рубашачку на ём папарвала,

Хромавы сапожыкі на ём памурала.

Пашоў жа малойчык, пашоў дый заплакаў.

Як стала дзяўчоначцы малойчыка жалка,

Як стала дзяўчоначка яго выклікаці:

Вярнісь, вярнісь Васілька, вярніся назад,

Сітцавую рубашачку я пазашываю,

Хромавыя чабоцікі я паабціраю....

Намеченный в этой теме мотив «незрелости» парня наблюдается в подобном тексте и д. Акшинка Ветковского р-на, где за “молодца" вступается его мать:

Нашто мяне, маменька, на гора радзіла, Красівая дзевачка мяне не ўзлюбіла,

Русыя кудзёрачкі на ім пабурыла,

Шоўкаву рубашачку яна расчыніла,

Лакавы сапожыкі яна памарала.

Пайдзём-ка, мой сыночак, да тыя дзеўчоначкі,

У гәтай дзяўчоначкі млады папытаем:

Як цябе, дзяўчоначка, як цябе ня стыдна, Зачым майго сынечку ты не ўзлюбіла?

А стала дзяўчоначцы малойчыка жалка, Стала дзяўчоначка хлопчыка збіраці...

(Штейнер 2003: 112).

На вопрос девушки, как относиться к будущему мужу, отец и мать дают разные советы. Мнение отца при этом отражает 
требование социума уважать супруга: «...Парай, мой татка, як з нялюбыли жыці? / / Хоць ня люб табе, заві любенькі, / / Хоць ня міл табе, заві міленькі...». ${ }^{9}$ Советы матери противоположны:

...А як жа мне маці, да старога абнімаці,

А як жа мне, маці, да старога цалаваці?

А як жа мне, маці, да старому пасцель слаці?

Пасцялі, дзіцятачка, тры рады палення,

Тры рады палення, а чацьвёртае - камення...

.... А як жа мне, маці, маладому пасцель слаці?

Пасцялі, дзіцятачка, тры рады падушак,

Тры рады падушак, а чацвертае - пярына...

(Новак 2002: 207).

Своеволие молодой жены можно наблюдать в текстах песен «На вуліцы дзеўкі гулялі...», где она «нанимает музыкантов», чтобы повеселиться с девушками. Заметим, что в данной традиции именно девушки «нанимали музыкантов» (приглашали и платили за игру) во время колядных молодежных вечерок. При этом она сама определяет время окончания веселья и не торопится домой, ведет себя как девушка:

...Гуляйце, дзеўкі, да свету,

Да позняга абеду,

Да ранняга снедання,

Да свякрухінага гукання,

Да свекравага пытання. ...

Пеўні пяюць - я ня йду,

Другія пяюць - я у танку,

Трэція пяюць - схамяну...

Некоторую защиту женщина надеется получить от деверя, сделав ему подарок:

...Дзеверьку ў ножкі пакланюсь.

- А ты, дзеверька, родны брат, ...

Вядзі мяне дадому,

У сьвекраву камору,

Дам табе хусту да долу,

Як муж біць будзя - уступісь,

А цалаваць будзя - атыйдзісь

(Кавалёва 2015: 108).

Открытая угроза нелюбимому/старому мужу также возможна со стороны молодой жены: «...Сала пайду за вадою, вазьлу 
старага з сабою, // кіну у проруб галавою, / / А сала 'стануся удавою, мае дзеткі сіратою» ${ }^{10}$. В этом отношении текст неглюбской песни перекликается с песней из соседней д. Столбун Ветковского района: «Жана ж мужа не ўзлюбіла, ... // Узяла травачкі купіла... // Свайго мужа отравіла... // У садочку схараніла... (БФ 1989: 83-83).

Тема женской и девичьей агрессии данных песен продолжает тему «умирания» мужа в тексте основной «стрельной» песни:

Да й ішла стряла у канец сяла,

Ой, люлі, у канец сяла.

Да ў канец сяла, ў канец Неглюбкі, ... да й да цәркайкі.

Убіла стряла добрага молайца.

Па том молайцу некаму плакаці -

Матка старанька, сястра маленька, Жана молада, дзеткі дробныя...

(БФ 1989: 67-68).

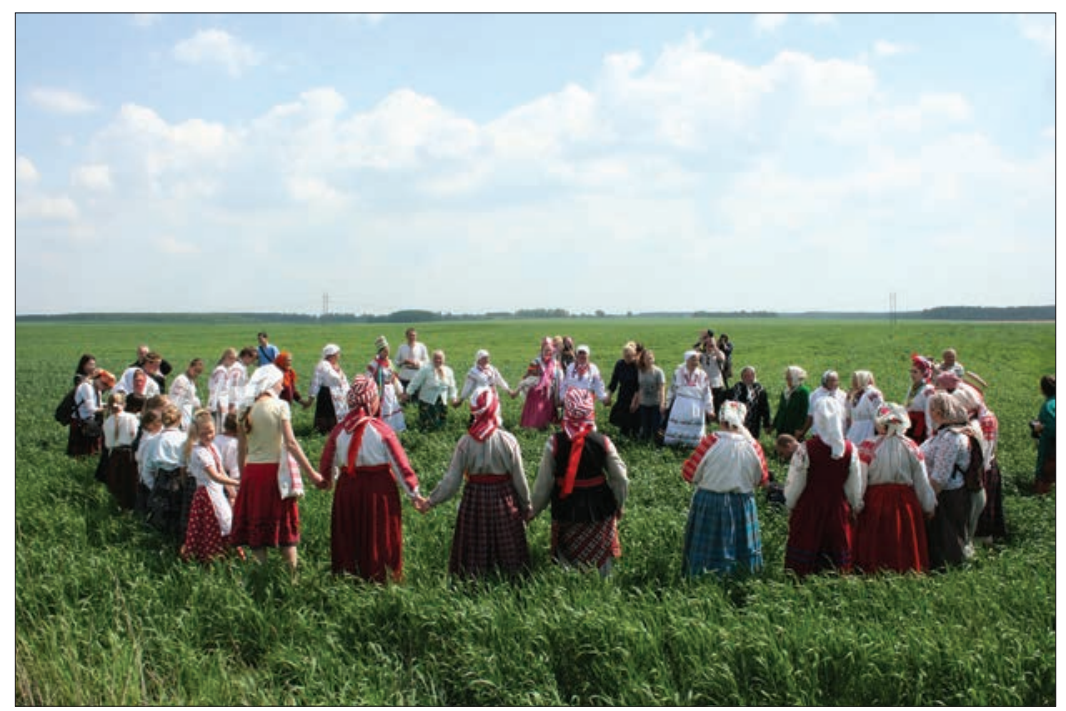

Фото 4. Обряд вождения Стрелы. Хоровод в поле. д. Столбун, Ветковский р-н, Гомельская обл. Республика Беларусь. Фото И. Ю. Смирновой, 2015. 
Особо хочется остановиться на таких театрализованных моментах праздника, как хоровод "Дрям $а$ » и действия с участием «старцов». Именно в этой части обряда главные роли принадлежат представителям группы старших женщин, которые изображали «Дряму» и «старцов» (или мужской персонаж из этой пары). Кроме того, по мнению исследователей, «напевы «Старца» и «Дрямы» близкие по характеру звучания, создают отдельный звуковой код в обряде» (Кавалёва 2015: 93).

Хоровод «Дряма» образуется вокруг старухи, которая сидит на перекрестке с прялкой и куделей, изображая процесс прядения, время от времени “задремывает”, внезапно просыпается и бьет (колет) веретеном участниц хоровода. «Ой, Дрёл-Дряла, ой, Дрёл-Дряла, задрялала / Над белаю, над кудзеляю, над бельли кужалёчкал..." - ну і абратна зноў начынае. А баба дрэлле, ... карагод пяе. Яна дзелала від, што спіць... яна во скубне, а бабы пяюць. Яна во скубне, і сплюшча вочы. I во - бух адналу па каленьках, тадь - бух! - друголу па каленьках, вераиянол" (Раманава 2004: 193). Девушки в хороводе вокруг старухи поют: «Не дрёл, дрёла, над кудзеляй, / / Не дрёл, дрёма, пад шаўковай. // Уставай, дрёма, ... хату месці, ... - госиі едуць. //...Я не устану хату месиі...». «Дрема» отвечает так на сообщение, что едет свекор, свекровь, отец, мать. Когда же ей сообщают, что «мілы едзе», она подхватывается и начинает «мести хату» (Ліцьвінка 1998: 95). Текст песни повторяется около десяти раз, по окончании пения девушки выводят круглый хоровод в более сложный - хоровод «Лука».

Сам персонаж «Дряма» отсылает нас к славянской мифологии, где веретено и кудель выступают в качестве неизменных спутников женских мифологических персонажей, наделяющих смертных судьбой и долей. В самом процессе прядения метафорически воплотились символика нити, идея творения плоти и мифологема непрекращающейся жизни. Сама пряжа и процесс прядения, таким образом, могут рассматриваться как образ умножения жизненной ткани и воспроизведения человека и рода в потомстве (Иванов 1983: 195). Попытка уколоть веретеном девушек-участниц обряда также обретает особое символическое значение в обряде. Хороводы заканчиваются, когда к месту сбора подходят «старцы», после чего участники направляются в поле, «в жито». 
Важная роль этих персонажей, связанная с продуцирующей и охранительной магией, подчеркивается тем, что они возглавляют шествие по улицам, первыми выходят в поле. Кульминационный момент обряда в Неглюбке называется «хаваць старца, прывязаць старца к жыту»: при выходе в поле «старцы» качаются по житу, изображая соитие. «А па вуліць пройдал, ...як канчаел, так ідом ідзе жьта, стариа хавалі. А у нас названіе - стариа схавалі, прывязалі яго к жыту. А яго ніхто не прывязываў к жыту! Пакачяещиа той старац, да старчьха па жыту, паваляюица, $i$ назад тады».. ${ }^{11}$

Характеристике и роли таких персонажей обряда как «старцы» исследователи уделили недостаточно внимания. Согласно сведениям информантов, «старцы»- пара ряженых, изображающие мужчину и женщину, с ярко выраженными половыми признаками. Травестированная пара одета в старые, грязные одежды, их лица вымазаны сажей или прикрыты тканью. В руках «старца» - палка («цапок») или «булава», скрученная из ткани, которым он угрожает присутствующим. «У канщь дзярэўні вадзілі карагоды, тал “дзелалі стариа”. Етазначьцы, надзяваліся два чалавекі. Мужчына надзявауся ў сарочку бабскую, андарак, карсет, завязвалі ялу неглюбскі чуб, лічо абпіналі марляй иі шчэ чьлм-небудзь, штоб ня відна было, аблазующиа сажай, абуюць валяниы. Баба надзявалася ў мужчынскія штаны, пінжак, сарочку. Тадьь ујжо “старць”" скачаць, прыдурююица, шььбаюиь иапкалы па дзеиях, якія бегаюиь збоку і паперяду і крычаць: “Дзед бабу паияряў, баба дзеда паияряла!"» (Новак 2002: 127). Во время движения «старцы» шутят, требуют выкуп за «взятых в плен», разыгрывают сценки фривольного содержания, грубо шутят на сексуальные темы (Кухаронак 2001: 97-98). Поскольку традиционная культура имеет ряд запретов на переодевание в одежду противоположного пола, «безопасное» выполнение этих ролей возможно только при условии остаться не узнанными. По мнению Ивлевой, подобные персонажи «ведут себя подобно клоунам, но, кривляясь и гримасничая, они тем самым как бы возвращают в человеческий коллектив мифических предков, «воплощают» их и наглядно демонстрируют фоизческий контакт живых и мертвых» (Ивлева 1994: 118).

Интересен сам фракт участия в обряде девушек и ряженых «старцов», где в мужском костюме в качестве фраллического символа обыгрываются различные предметы (рукавица, скрученная 


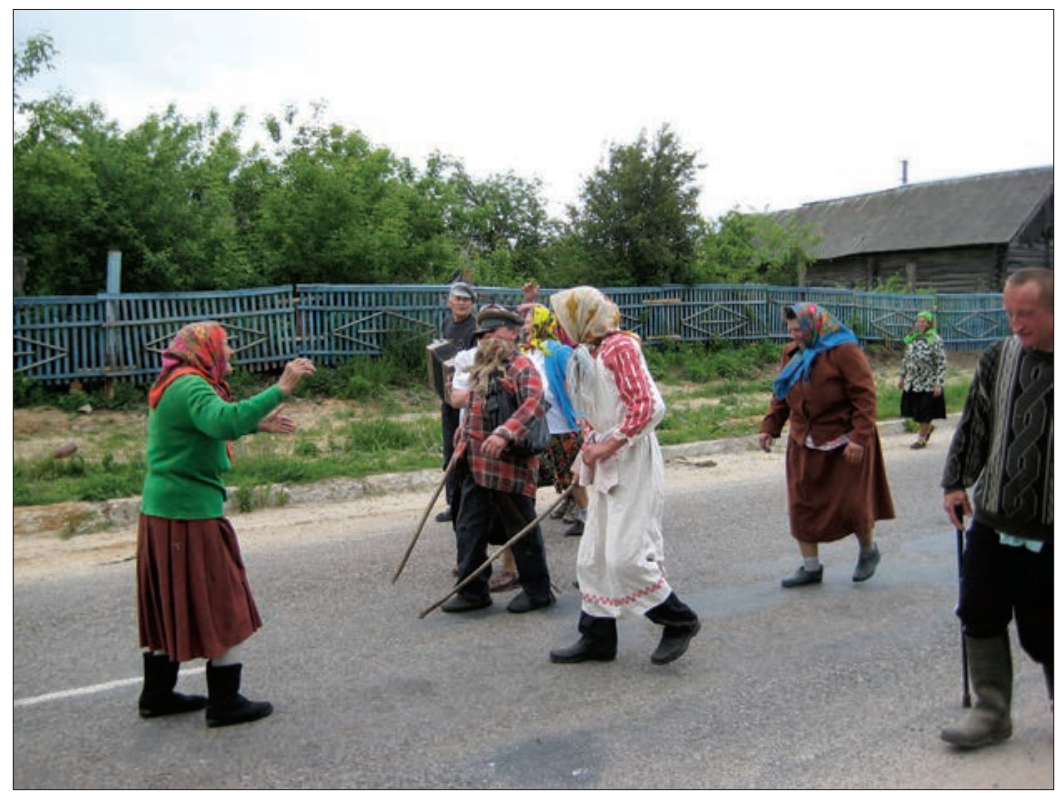

Фото 5. Обряд вождения Стрелы. Ряженые-«старцы». д. Неглюбка, Ветковский р-н, Гомельская обл. Республика Беларусь. Фото И. Ю. Смирновой, 2009.

красная ткань, морковь, лук и т.д.). Выше мы говорили об этапах перехода девушки в группу старших («невест»), значительную роль в которых принадлежала осенним и колядным вечеркам. В Неглюбке такие посиделки имели отголоски "древней организации “женского дома”, где девушки имели главенствующую роль» (Бернштам 1988: 239-240). Именно в это время обыгрывались «брачные отношения» между парнями и девушками, частью которых были игры с эротическим подтекстом (в частности, атрибут «старца» - «булава» из ткани, с узлом на конце, использовалась в молодежной игре «У джгута»). М. Л. Лурье рассматривал комплекс посиделочных игр как своеобразную сексуально-игровую инициацию, в первую очередь для девушек (Лурье 1995: 182-183). С большой долей вероятности участие «старцов» в обряде вождения «Стрелы» является продолжением такого рода инициации, во время которой «от девушки требовалось преодолеть эмоциональный барьер, действовать вопреки 
чувству смущения и неловкости, предстать «бойкой», с другой засвидетельствовать перед обществом свою целомудренность, продемонстрировав девическую стыдливость» (Лурье 1999: 10).

Таким образом, обряд вождения «Стрелы», главными участниками которого были совершеннолетние девушки, рассматривается как ритуальное единение женского коллектива, пик девичьей зрелости и активности. В текстах «стрельных» песен ярко выражена оппозиция женский/мужской (девушки/парни), где двойственность проявляется как интерес, влечение к мужскому началу и агрессивность по отношению к нему, готовность к браку и его отрицание, желание покинуть родительский дом и стремление к свободной жизни. Обряд «Вождение стрелы» является последним, переходным этапом на пути к девичьему совершеннолетию, в качестве моментов инициации выступают выход девушек перед обществом в качестве невесты (в полном праздничном костюме), коллективное единение в обрядовых действиях (игры, хороводы, выход в поле) и исполнении приуроченных к обряду песен.

\section{Примечания}

1 Зап. в 2005 г. И. Ю. Смирнова в п. Селище Ветковского р-на Гомельской обл. от Суглоб А. С., 1929 г.р.

2 Зап. в 2005 г. И. Ю. Смирнова в п. Селище Ветковского р-на Гомельской обл. от Суглоб А. С., 1929 г.р.

3 Зап. в 2004 г. И. Ю. Смирнова в п. Селище Ветковского р-на Гомельской обл. от Суглоб А. С., 1929 г.р.

4 Зап. в 2004 г. И. В. Мазюк, Т. А. Пладунова в д. Неглюбка Ветковского р-на Гомельской обл. от Соломенной У. М., Демчихиной Е. И.

5 Зап. в 2003 г. И. Ю. Смирнова в д. Неглюбка Ветковского р-на Гомельской обл. от Герасименко М. Г., 1928 г.р., Барсуково С. Г., 1935 г.р.

6 Зап. в 2004 г. И. В. Мазюк, Т. А. Пладунова в д. Неглюбка Ветковского р-на Гомельской обл. от Соломенной У. М., Демчихиной Е. И.

7 Зап. в 2004 г. И. Ю. Смирнова в п. Селище Ветковского р-на Гомельской обл. от Суглоб А. С., 1929 г.р.

8 Зап. в 2004 г. И. Ю. Смирнова в п. Селище Ветковского р-на Гомельской обл. от Суглоб А. С., 1929 г.р. 
9 Зап. в 2005 г. И. Ю. Смирнова в п. Селище Ветковского р-на Гомельской обл. от Суглоб А. С., 1929 г.р.

10 Зап. в 2004 г. И. Ю. Смирнова в п. Селище Ветковского р-на Гомельской обл. от Суглоб А. С., 1929 г.р.

11 Зап. в 2004 г. И. Ю. Смирнова в п. Селище Ветковского р-на Гомельской обл. от Суглоб А. С., 1929 г.р.

\section{Литература}

БФ 1989. Беларускі фбальклор у сучасных запісах: Традыцыйныл жанры: Голельская вобл. Мінск: Універсітэцкае.

Бернштам, Татьяна 1988. Молодежь в обрядовой жизни общины ХIXначала XX в.: половозрастной аспект традииионной культуры. Ленинград: Наука, Ленингр. отд-ние.

Бернштам, Татьяна 1982. Орнитоморфная символика у восточных славян. Советская этнография 1, сс. 82-100.

Геннеп, Арнольд ван 1999. Обряды перехода. Систематическое изучение обрядов. Москва: Издательская фирма «Восточная литература» $\mathrm{PAH}$.

Гусев, Виктор 1986. Вождение «стрелы» («сулы») в Восточном Полесье. Славянский и балканский фольклор: Духовная культура Полесья на общеславянскол фбоне. Москва: Наука, сс. 63-75.

Иванов, Вячеслав 1982. К реконструкции Мокоши как женского персонажа в славянской версии основного мифа. Балто-славянские исследования. Москва: Наука, сс. 175-197.

Ивлева, Лариса 1994. Ряженье в русской традииионной культуре. Санкт-Петербург: Рос. Ин-т истории искусств.

Каршукоў, М. 1926. Пахаванне стралы. Наш край. Менск 1, сс. 41-42.

Кухаронак, Таццяна 2001. Маскі ў каляндарнай абраднасці беларусаў. Мінск: Навука і тәхніка.

Кавалёва, Рыма 2015. Лакальна-рэгіянальныя парадыгмы беларускага фбальклору. Ч. 3. Мінск: БДУ.

Лебедева, Наталия 1996. Народный быт в верховьях Десны и верховьях Оки (этнографическая экспедиция в Брянской и Калужской 
губерниях в 1925-ом и 1926-и годах). Рязанский этнографбический вестник. Т. 1. Рязань, сс. 31-92.

Ліцьвінка, Васіль 1998. Святы і абрады беларусаў. Мінск: Беларусь.

Лурье, Михаил 1995. Эротические игры ряженых в русской традиции (по дореволюционным публикациям и современным записям). Русский эротический Фольклор: Песни. Обряды и обрядовый Фольклор. Народный театр. Заговоры. Загадки. Частушки. Москва: Ладомир, сс. 177-183.

Лурье, Михаил 1999. Посиделочные игры святочного ряженыя: опыт морфбологического описания: Автореф. дис. на соиск. учен. степ. канд. Искусствоведения : 17.00.09. Санкт-Петербург. М-во культуры Рос. Федерации, Рос. акад. наук, Рос. ин-т истории искусств.

Новак, Валянціна 2002. Абраднасиь і паэзія пахавання стралы. Гомель: Гомел. дзярж. ун-т.

Раманава, Ларыса 2004. Калі разгараещца сад чаўнакоў? (Каляндар прадзення і ткацтва. Этнаграфічныя заўвагі). Навуковыя запіскі Веткаўскага музея народнай творчасиі. Гомель: Гомел. дзярж. ун-т, сс. 168-230.

Романов, Евдоким 1912. Белорусский сборник. Вып. 8: Быт беларуса. Вильна: Тип. А. Г. Сыркина.

Смирнова, Ирина. "Да й ішла стряла у канеи сяла, у канеи Неглюбкі...” Весенние обряды в жизни молодежи. Русские традиции. Альманах русской традиционной культуры. http://www.ruplace.ru/etnologiya/ da-y-ishla-stryala-u-kanets-syala-u-kanets-neglyubki-.-vesennieobryady-v-zhizni-molodezhi.html (дата обращения 20.09.2017).

Смирнова, Ирина 2004. Из истории села Неглюбка. Навуковыљ запіскі Веткаўскага музея народнай творчасиі. Гомель: Гомел. дзярж. ун-т. сс. 80-106.

Смирнова, Ирина 2004а. Неглюбские молодежные вечера зимнего периода. Традыцыі матэрыяльнай $і$ духоўнай культуры Усходняга Палесся. Ч. 1. Гомель: УА “ГДУ імя Ф.Скарыны”, сс. 193-197.

Смирнова, Ирина 2008. Возрастная дифференциация женской одежды Неглюбского строя. Нацыянальны касиюл у сучаснай сацыякультурнай прасторы: зб. арт. Мінск: БДУ культуры і мастацтваў, cc. 93-98. 
Супинский, Антон 1932. «Понева» и «вставка» в белорусской женской одежде (К вопросу об их культовом происхождении). Советская этнограбия 2, сс. 102-136.

Штейнер, Іван 2003. Вечнае: Фальклорна-этнаграфічная спадчына Веткаўскага раёна. Гомель: УА «ГДУ імя Ф. Скарыны».

\section{Summary}

\section{Gender Aspect of "Arrow Carrying” Ritual (Belarusian-Russian Borderland)}

\section{Irina Smirnova}

Keywords: gender opposition in a ritual, rites of passage, spring rituals The ritual of "arrow" carrying that was mostly conducted by young adult girls is considered to represent the ritual unity of females, the peak of girls' maturity and activity. There is a clear opposition between feminine and masculine in the texts of the "arrow" songs. The ambiguity is manifested through the interest towards the masculine but also through aggression towards it. The ritual of "arrow" carrying is the last step in the transition to female adulthood. The study is based on the tradition of Neglyubka village, Vetka District, Gomel Region, Belarus. 


\section{МИССИЯ ВЫПОЛНИМА Перспективы изучения фольклора}

http://www.folklore.ee/rl/pubte/ee/sator/sator19/

ISSN 1736-0323

ISBN 978-9949-586-60-8

DOI: $10.7592 /$ Sator.2018.19

Тарту 2018

Редакторы-составители выпуска:

Маре Кыйва \& Татьяна Володина

Редактор серии: Маре Кыйва

Фото: Яак Кикас, 2018 «Осень в Тарту»

Оформление обложки: Лииса Весик

Верстка \& HTML: Диана Кахре

Печатное издание: МИССИЯ ВЫПОЛНИМА:

Перспективы изучения фольклора. SATOR 19. Тарту 2018

Публикация книги осуществлена совместно Эстонским литературным музеем и Центром исследований белорусской культуры, языка и лит ерат уры Националь ной акад емии наук Б еларус и, п ри поддержке Министерства образования и науки Эстонии (IUT 22-5), Фонда регионального развития ЕС (ТK 145, Центр компетенции по Эстонским исследованиям); при поддержке проекта, финансируемого Министерством иностранных дел Эстонии из бюджета по сотрудничеству и развитию, Эстонской Академией Наук и Национальной академии наук Беларуси.

Оформление электронного издания осуществлено при поддержке проекта ЕККМ14-344 “Расширение областей применения и представление эстонского языка, культуры и фольклора в электронных информационных средствах".

() Эстонский литературный музей

(c) Авторы

(с) Яак Кикас 